УДК $338.1+330.35$

DOI: 10.25140/2411-5215-2020-2(22)-18-30

\author{
Вікторія Рудевська
}

\title{
ЕВОЛЮЦІЯ ТЕОРІЙ ЕКОНОМІЧНОГО ЗРОСТАННЯ ТА ЧИННИКИ ЙОГО ОЦІНЮВАННЯ
}

\author{
Виктория Рудевская \\ ЭВОЛЮЦИЯ ТЕОРИЙ ЭКОНОМИЧЕСКОГО РОСТА \\ И ФАКТОРЫ ЕГО ОЦЕНКИ
}

\author{
Viktoria Rudevska \\ ECONOMIC GROWTH THEORY EVOLUTION \\ AND ITS EVALUATION FACTORS
}

\begin{abstract}
У статті досліджено наукові підходи до визначення сутності економічного зростання. У процесі аналізу виявлено, щзо в науковому середовищі існує плюралізм у трактуванні економічного зростання та відсутнє чітке розмежування понять «економічне зростання» та «економічний розвиток». Розглянуто історичний розвиток теорій економічного зростання, щзо свідчить про підвищення ролі економічного зростання в прочесі формування сучасних конщепцій розвитку держави. У дослідженні обтрунтовано авторське трактування економічного зростання як пріоритетної иілі держави. Наведено дослідження наукових підходів до визначення чинників оцінювання економічного зростання та акиентовано на різність трактувань в економічній науковій літературі. Важливо, щяо економічне зростання може бути як позитивним, так і негативним. Сформовано головні принципи та типи економічного зростання. Розгляд еволюції теорій економічного зростання показав адаптацію різних підходів до інновачійних змін в економіці.
\end{abstract}

Ключові слова: економічне зростання; економічний розвиток; економічна політика; ВВП.

Рис.: 3. Табл.: 2. Бібл.: 33.

В статье исследованы научные подходы к определению сущности экономического роста. В ходе анализа выявлено, что в научной среде существует плюрализм мнений в трактовке экономического роста и отсутствует четкое разграничение понятий «экономического роста» и «экономического развития». Рассмотрена эволючия теорий экономического роста, что свидетельствует о повышении роли экономического роста в прочессе формирования современных концепций развития государства. В исследовании представлена собственная трактовка экономического роста как приоритетной иели развития государства. Рассмотрены научные подходы к определению факторов оценки экономического роста и акцентировано на различиях в их описании в научной литературе. Важно, что экономический рост может иметь как положительное, так и отрииательное значение. Представлены главные принципы и типы экономического роста. Анализ эволющии теорий экономического роста показал адаптацию различных подходов к инновачионным изменениям в экономике.

Ключевые слова: экономический рост; экономическое развитие; экономическая политика; ВВП.

Рис.: 3. Табл.: 2. Библ.: 33.

The article explores the scientific approaches to determine the essence of economic growth. The analysis revealed that in the scientific community there is a pluralism in the interpretation of the essence of economic growth and there is no clear distinction between the concepts of "economic growth" and "economic development". The article discusses the evolution of theories of economic growth, which indicates the increasing role of economic growth in the formation of modern concepts of state development. The study presents its own interpretation of economic growth. It is based on statement that the economic growth is a priority goal of state development. The article considers the scientific approaches to the determination of factors for economic growth's measuring and focuses on the differences in their description in the scientific literature. It is important that economic growth can be both positive and negative. The article presents the main principles and types of economic growth. An analysis of the evolution of theories of economic growth showed the adaptation of various approaches to innovative changes in the economy.

Keywords: economic growth; economic development; economic policy; GDP.

Fig.: 3. Table: 2. References: 33.

JEL Classification: E32

Постановка проблеми. Проблема економічного зростання як мета держави сьогодні посідає одне 3 провідних місць у системі досліджень науковців та викликає багато запитань у сфері державного управління. Динамічний розвиток економічних процесів сприяє постійній мінливості впливу чинників на розвиток економіки країни. Так, ті ж самі фактори можуть мати різну вагу в певний момент часу. Теоретичні дослідження в цій сфері зосереджуються на підходах до визначення понять «економічний розвиток», «економічне зростання», «економічна політика» та пошуку детермінант впливу на них. Прикладний характер пояснює взаємозв'язки та принципи функціонування моделі економічного зростання, а також описує систему кількісних та якісних показників економічної системи.

(C) Рудевська B. I., 2020 
ТЕОРЕТИЧНІ ПРОБЛЕМИ РОЗВИТКУ НАЦІОНАЛЬНОЇ ЕКОНОМІКИ

Аналіз останніх досліджень і публікацій. Вважається, що розрізнення термінів «зростання економіки» та «економічний розвиток» вперше в 1911 році здійснив Йозеф Алоїз Шумпетер, що знайшло також своє відображення у праці «Теорія економічного розвитку» (1939) [32]. Крім Й. Шумпетера, одним із перших тлумачення поняття «економічне зростання» надав також Саймон Кузнець, порівняно з аналогією розвитку живих організмів [26]. Значний внесок у розвиток теорій економічного зростання зробили С. Кузнець, М. Портер, Р. Солоу, Ф. Бродель, І. Гілл, М. Райзер, П. Ромер, Р. Лукасмолодший, М. Спігель, Дж. Бенхабіб та багато інших. Проте до сьогодні немає єдиної думки та загальноприйнятого підходу щодо визначення поняття «економічне зростання» та чіткого розмежування його 3 «економічним розвитком». Можна стверджувати, що ідеологічно, проблема економічного зростання є дилемою вибору «минуле - майбутнє»: як суспільство повинно здійснити розподіл ресурсів між поточними потребами та майбутніми через рік, десятиліття, століття.

Виділення недосліджених частин загальної проблеми. Можна виділити низку основних проблем, які виникають при формуванні концепції економічного зростання:

- взаємозв'язок економічного зростання та економічного розвитку;

- взаємозв'язок економічного зростання та економічної політики;

- кількісний та якісний перехід економічного зростання [3, с. 32]. Вирішення окреслених проблем вимагає подальшого дослідження та грунтовного аналізу. Якісна динаміка концепцій економічного зростання є вершиною еволюції економічного розвитку та збалансування інтересів суб'єктів господарювання, яка потребує постійного вивчення.

Мета статті. Здійснити огляд трактувань поняття «економічне зростання» та узагальнити наявні підходи різних концепцій економічного зростання. Головною метою цієї роботи є дослідити процес еволюції визначень і чинників економічного зростання та запропонувати авторське визначення економічного зростання за принципом розмежування економічної динаміки.

Виклад основного матеріалу. Популярність та актуальність дослідження проблем економічного зростання зумовила розвиток різних теорій та підходів до обгрунтування його змісту. Й. Шумпетер визначив «економічне зростання» як кількісні зміни збільшення виробництва та споживання товарів та послуг у різний період часу [24, с. 159]. На думку Й. Шумпетера, економічне зростання є наслідком «процесу творчого руйнування» та інновацій, що випливає з двоїстого характеру технічного прогресу:

- створення нових продуктів чи процесів з метою очікування ренти у випадку успішного завойовування ринку;

- анулювання застарілих технологій та «руйнація» ренти попередніх інновацій $[10$, c. 24$]$.

Отже, відповідно до теорії Й. Шумпетера, поняття «економічне зростання» характеризується кількісною зміною показників економіки, що робить його вужчим від поняття «економічний розвиток», яке визначається також і якісними змінами.

Розглянемо генезис теорій економічного зростання за еволюційно-змістовим підходом.

Класична теорія зростання визначає економічне зростання величиною факторів виробництва та їх продуктивністю. Прибічники класичної теорії вважали, що основою економічного зростання має бути нагромадження, яке грунтується на падінні норми прибутку в довгостроковому періоді.

Модель Р. Солоу (1956) [33] сформувала неокласичну теорію зростання. Р. Солоу вдалося змоделювати економічне зростання на основі взаємозв'язку між капіталом, випуском продукції, інвестиціями та робочим часом. Поєднання цих компонентів відображає виробничу функцію. 3 часом ця модель трансформувалась і тепер називається модель Солоу-Свона (модель довгострокового зростання). На відміну від класиків, нео- 
класики вважили чинник науково-технічного прогресу вирішальним у процесі економічного зростання. Теорія Солоу не враховує різні ставки дохідності інвестицій та зменшення життєвого циклу активів, що вважається недоліком неокласичної теорії зростання. Перевагою цієї неокласичної моделі $є$ визначення зовнішніх демографічних детермінант (чисельність населення, структура трудових ресурсів, продуктивність праці) впливу на довготривале зростання. Недоліком є те, що вона не пояснює зростання чисельності населення, технологічний процес та процес накопичення знань.

Досить цікавою є теорія стадій економічного зростання (представник У. Ростоу). У цій теорії визначається шість стадій економічного зростання (спочатку було три, а потім п'ять): традиційне суспільство, створення передумов «злету», «зліт»; рух до зрілості, епоха високого масового споживання, пошук якості життя [30, с. 307-331]. По суті, У. Ростоу у своїй теорії наріжним каменем ставить духовний розвиток людини.

Представники ендогенної теорії зростання Р. Лукас та П. Ромер (кінець 80-х - початок 90-х рр. ХХ ст.) спробували пояснити технологічний процес математичними методами та довели, що людський капітал та інновації значно підвищують продуктивність праці. Ендогенна теорія зростання значно розвинулась у 1994 році, коли М. Спігель та Дж. Бенхабіб дослідили, що людський капітал не є детермінантою технології, а $є$ функцією технології виробництва [25, с. 172]. Окремо варто зазначити моделі Ф. Агійона (1990) та П. Хоувітта (1992), які пояснюють економічне зростання науково-технічним прогресом та зростання зайнятості в секторі конструкторських розробок через трансмісію технологічних інновацій та конкуренції [1, с. 19]. Існує також узагальнююча теорія економічного зростання О. Галора, яка доповнює теорію ендогенного зростання та узгоджує процес розвитку. Ці моделі найкраще ілюструють концептуальний підхід Й. Шумпетера, який пояснює формат «зростання» кількісними змінами, а «розвиток»- якісними.

Одним із мейнстримів сучасної економічної теорії $є$ новокейнсіанська модель, яка $\epsilon$ більш динамічною в порівнянні з неокейнсіанською. Новий кейнсіанський підхід передбачає більший ефект від використання інструментів фіскальної та монетарної політики для досягнення макроекономічної стабілізації. Новокейнсіанці вважають, що монетарна політика має значний вплив на інфляцію та економічне зростання. Новокейнсіанські економічні моделі розглядають економічні процеси в динаміці та на цій основі пропонують сформувати оптимальну економічну політику з активним використанням однієї з їі складових - таргетування інфляції [2, с. 95].

Представники теорії економічного зростання С. Брю та М. Макконел пояснюють економічне зростання часом виробничих можливостей та ефективністю економічної політики, що дозволить збільшити обсяг ВВП [10, с. 28]. Вони визначили залежність економічного зростання від чинників пропозиції за матеріальною ознакою, які сприяють розширенню виробництва.

Розвиток теорій економічного зростання зумовив різноманіття та багатогранність тлумачення поняття «економічне зростання». Важливо в цьому контексті розглянути дефініції поняття «економічне зростання». Огляд трактувань сутності поняття «економічного зростання» в науковій літературі відображено в табл. 1.

Таблиця 1

Огляд трактувань сутності поняття «економічне зростання»

\begin{tabular}{|l|c|}
\hline \multicolumn{1}{|c|}{ Трактування } & Автор, джерело \\
\hline \multicolumn{1}{|c|}{1} & 2 \\
\hline $\begin{array}{l}\text { Економічне зростання - це процес формування приросту фізичного обсягу національного } \\
\text { чи світового продукту в його оптимальній натурально-речовій структурі. Процес ство- } \\
\text { рення приросту реального ВВП у будь-яких масштабних господарських системах. }\end{array}$ & $\begin{array}{c}\text { Сайчук В. Ф. } \\
{[17, \text { с. 65] }}\end{array}$ \\
\hline $\begin{array}{l}\text { Економічне зростання - це процес, що складається з окремих взаємодій, у результаті } \\
\text { яких економічна матерія надходить у національну економіку та передається від однієї } \\
\text { їі частини до іншої. }\end{array}$ & $\begin{array}{c}\text { Кузнець С. } \\
{[27, \text { с. 11] }}\end{array}$ \\
\hline
\end{tabular}


Закінчення табл. 1

\begin{tabular}{|c|c|}
\hline 1 & 2 \\
\hline $\begin{array}{l}\text { Економічне зростання - це процес кількісно-якісних зрушень у межах технологічного } \\
\text { способу виробництва, зумовлених відповідними суперечностями та чинниками і який } \\
\text { виражається у збільшенні обсягів суспільного виробництва. }\end{array}$ & $\begin{array}{c}\text { Мочерний С. В. } \\
{[9, \text { с. 28] }}\end{array}$ \\
\hline $\begin{array}{l}\text { Економічне зростання - довгострокове збільшення обсягів виробництва з метою все- } \\
\text { бічного задоволення потреб населення, яке відбувається за умов розширеного відтво- } \\
\text { рення, забезпеченого за рахунок покращення якості його факторів, технологічного } \\
\text { оновлення, всебічного розвитку особистості та раціонального природокористування, i } \\
\text { обов'язково супроводжується поліпшенням якісних ознак. }\end{array}$ & $\begin{array}{c}\text { Хоменко Я. В. } \\
{[21, \text { с. 494] }}\end{array}$ \\
\hline $\begin{array}{l}\text { Термін «економічне зростання» належить до збільшення (або зростання) конкретних по- } \\
\text { казників, таких як національний дохід, валовий внутрішній продукт (ВВП) або дохід на } \\
\text { душу населення. Зростання ВВП економісти характеризують як економічне зростання. }\end{array}$ & $\begin{array}{c}\text { Пилип’юк Я. В. } \\
{[13, \text { с. 110] }}\end{array}$ \\
\hline $\begin{array}{l}\text { Економічне зростання - це довготермінова тенденція збільшення обсягів сукупного } \\
\text { виробництва, яке відбувається в умовах структурної перебудови економіки відповід- } \\
\text { но до нормативних вимог соціального та технологічного прогресу, а також підвищен- } \\
\text { ня ефективності відтворювальних процесів. }\end{array}$ & $\begin{array}{l}\text { Піхняк Т. А., } \\
\text { Вінідіктова І. С., } \\
\text { Кабаці Б. І. } \\
\text { [14, с. } 135]\end{array}$ \\
\hline Економічне зростання - це один з аспектів процесу економічного розвитку. & $\begin{array}{c}\text { Сен А. } \\
{[31, \text { c. } 745]}\end{array}$ \\
\hline $\begin{array}{l}\text { Економічне зростання - це феномен збільшення величини ВВП, ВНД та інших альте- } \\
\text { рнативних показників, який демонструє збільшення здатності економічної системи } \\
\text { виробляти товари та послуги порівняно з одним періодом часу щодо іншого, відо- } \\
\text { бражаючи лише одну з граней економічного розвитку. }\end{array}$ & $\begin{array}{l}\text { Бобух I. М. } \\
{[10, \text { c. } 11-12]}\end{array}$ \\
\hline $\begin{array}{l}\text { Економічне зростання - це базова складова економічного розвитку, яка проявляється } \\
\text { у динаміці якісних та кількісних показників під впливом екзогенних та ендогенних } \\
\text { факторів економічного, організаційного, структурного, інституціонального характе- } \\
\text { ру, які тісно пов'язані з державним регулюванням, та характеризує процес певних } \\
\text { змін у макроекономічній системі та ефективності суспільного виробництва. }\end{array}$ & $\begin{array}{c}\text { Глуха Г. Я. } \\
{[3, \text { с. 37] }}\end{array}$ \\
\hline $\begin{array}{l}\text { Економічне зростання - це збільшення потенційного ВВП або випуску країни, що } \\
\text { настає тоді, коли границі виробничих можливостей розширюються. }\end{array}$ & $\begin{array}{l}\text { Самуельсон П. } \\
{[18]}\end{array}$ \\
\hline $\begin{array}{l}\text { Економічне зростання виступає важливою умовою розвитку, адже, з одного боку, } \\
\text { пов'язане } 3 \text { позитивною динамікою зміни абсолютних та відносних показників реаль- } \\
\text { ного ВВП (на душу населення), а з іншого - } 3 \text { формуванням економічних, соціальних } \\
\text { та природних умов для забезпечення якісних змін рівня та якості життя населення. }\end{array}$ & $\begin{array}{c}\text { Семків Л. Є. } \\
{[19, \text { с. 67] }}\end{array}$ \\
\hline $\begin{array}{l}\text { Економічне зростання є показником результативності функціонування національної } \\
\text { економіки, одним з найважливіших завдань сталого розвитку і підвищення рівня } \\
\text { життя населення, а дослідження його сутності має значний еволюційний шлях. Еко- } \\
\text { номічне зростання, з одного боку, пов'язане } з \text { позитивною динамікою реального об- } \\
\text { сягу виробництва, а з іншого - з удосконаленням технолого-економічних і соціальних } \\
\text { аспектів розвитку суспільства. Воно виражається в збільшенні реального ВВП і відо- } \\
\text { бражається статистичним показником - річним темпом росту ВВП у відсотках. }\end{array}$ & $\begin{array}{c}\text { Загорський В. С. } \\
{[5, \text { с. } 10,12]}\end{array}$ \\
\hline
\end{tabular}

Джерело: сформовано авторкою.

Еволюція теорій економічного зростання - це поступова засаднича відповідь економічної теорії на обмеженість ресурсів та виклики довкілля, що впливає на адаптацію різних підходів до інноваційних змін. Як видно з табл. 1, тлумачення поняття «економічне зростання» не має єдиного визначення та оперує різними показниками (від абсолютних до абстрактних). Економічне зростання - це, по суті, основна макроекономічна мета, досягнення якої стимулює економічну систему до зростання національного доходу на одиницю населення з одночасним підвищенням рівня добробуту. Одні вважають, що економічне зростання - це приріст валового внутрішнього продукту (далі - ВВП) та інших показників, інші - динаміка якісних характеристик економіки. Таке різноманіття підходів зумовлено різними концептуальними засадами розуміння економічного зростання. У науковій літературі відображені спроби уніфікувати ці підходи. Так, Г. Я. Глуха виділяє три основні підходи до визначення поняття «економічне зростання» (рис. 1). 
Підходи до визначення поняття «економічне зростання»

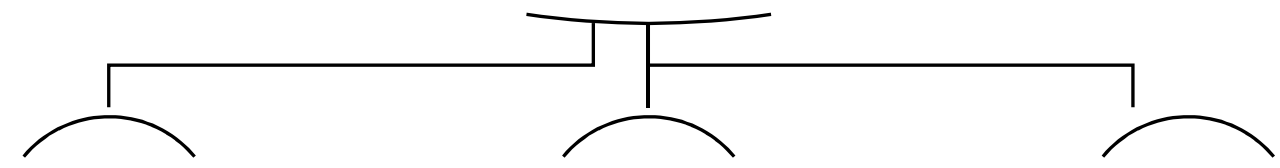

зміна абсолютних кількісних показників

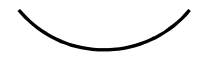

зміна відносних кількісних показників

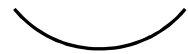

зміна якісних показників

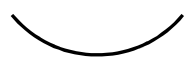

Рис. 1. Підходи до визначення поняття «економічне зростання»

Джерело: згруповано авторкою з використанням [3, с. 35-36].

Підхід «зміни абсолютних кількісних показників» характеризується зміною ВВП, національного доходу, обсягів міжнародних резервів чи національного багатства.

Підхід «зміни відносних кількісних показників» розглядає показники ВВП на душу населення, обсяг споживання на душу населення, дохід на душу населення.

Підхід «зміни якісних показників» формується на показниках рівня освіти населення, галузевої структури економіки, стану екологічного середовища, соціальної справедливості, політичної стабільності та інших чинників якості життя населення.

Проте такий підхід до визначення поняття економічного розвитку «розмиває» межу між економічним зростанням та економічним розвитком через включення зміни якісних показників.

3 огляду на вищезазначене «економічне зростання» можна визначити як пpiopumeтну мету держави, яка проявлясться у зростанні ВВП та інших альтернативних показників розвитку економічної системи, що забезпечує підвищення якості життя населення в прочесі суспільного відтворення. Таке визначення робить акцент на позитивній зміні кількісних показників та його вплив на зміну якісних показників як похідної від основного процесу. При ичьому враховано той факт, щэо оиінка зміни якісних показників має суб 'єктивний характер.

Отже, економічне зростання пов'язується з кількісною зміною обсягу виробництва $\mathrm{i}$ споживання валового внутрішнього продукту, а з погляду класичної економічної теорії економічне зростання $\epsilon$ найважливішою складовою частиною розвитку держави. Сьогодні точаться наукові дискусії щодо відповідності показника ВВП економічному зростанню. Однак на практиці, коли йдеться про економічне зростання, то мається на увазі саме кількісна зміна ВВП на душу населення. Тому можна вважати, що сучасна концепція економічного зростання тісно пов'язана з кількісним виміром макроекономічних показників, таких як ВВП, національний дохід, похідні показники, альтернативні показники.

Економічне зростання може бути позитивним та негативним. Коли обсяг реального ВВП в поточному періоді перевищує його рівень у базовому періоді, то таке зростання $\epsilon$ позитивним. Інакше його можна характеризувати як негативне [11].

При розробці чи вдосконаленні трактування поняття «економічне зростання» потрібно здійснювати пошук системи принципів дослідження цього явища чи процесу. За допомогою методів наукового аналізу такого процесу можна виділити такі головні принципи:

- принцип єдності ознак (загальних та специфічних) у межах країни [19, с. 67];

- принцип макроекономічного підходу (економіка країни, економіка регіону, економічний союз, світова економіка); 
ТЕОРЕТИЧНІ ПРОБЛЕМИ РОЗВИТКУ НАЦІОНАЛЬНОЇ ЕКОНОМІКИ

- принцип обов'язковості виділення об'єктів економічної діяльності;

- принцип збалансування кількісних та якісних ознак макропроцесів [12, с. 71];

- принцип визначення основних внутрішніх та зовнішніх чинників впливу;

- принцип визначення системи показників для можливості порівняння різних регіонів чи країн [3, с. 37];

- принцип розмежування економічної динаміки зростання, розвитку, прогресу, збільшення виробництва та суспільного відтворення;

- принцип врахування умов (економічних, соціальних, культурних, історичних) [22, c. 194];

- принцип активізації інвестиційного потенціалу [16];

- принцип «rent-seeking behavior» (реального функціонування економіки з інституційними провалами та якісними змінами структури) [4];

- принцип цілісності, системності, ієрархічності та структурності [20, с. 51].

Розмежування економічної динаміки дає можливість виділити економічне зростання як іiі різновид із певними специфічними ознаками (рис. 2).

Ознаки економічного зростання

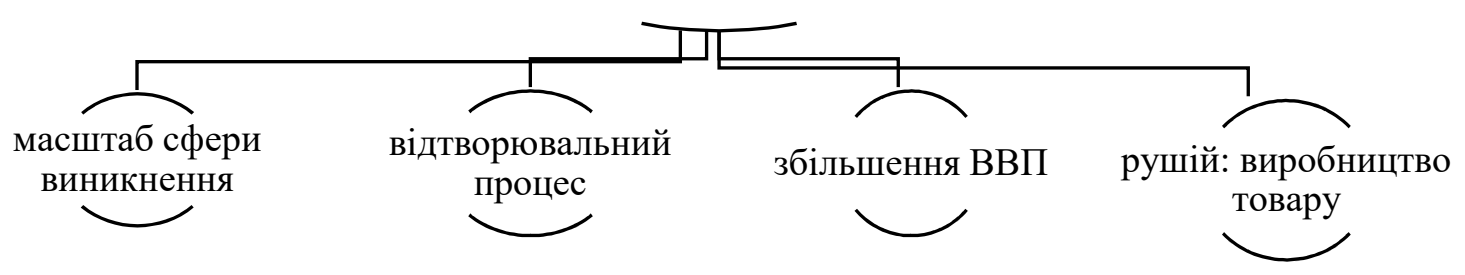

Рис. 2. Специфічні ознаки економічного зростання

Джерело: сформовано автором з використанням [27, с. 32].

Проблема економічного зростання $є$ досить широкою та багатогранною. В. С. Загорський у монографії «Концептуальні основи формування системи управління сталим розвитком еколого-економічних систем» виділяє три форми економічного зростання:

- стійке зростання, яке характеризується ринковим та збалансованим накопиченням активів, наявністю значних субвенцій та гарантій на захист природних ресурсів, розвитком освіти та системи охорони здоров'я;

- нестійке зростання - характеризується зниженням темпів зростання, що переходить у процес стагнації, однак можуть бути сплески коротких періодів швидкого зростання;

- спотворене зростання, яке досягається завдяки субсидуванню фізичного капіталу та погіршенню якості природних ресурсів [5, с. 22].

Найбільш поширеною класифікацією типів економічного зростання $є$ його поділ за способами нарощування виробництва та якісного відновлення процесів розширеного відтворення (рис. 3). 


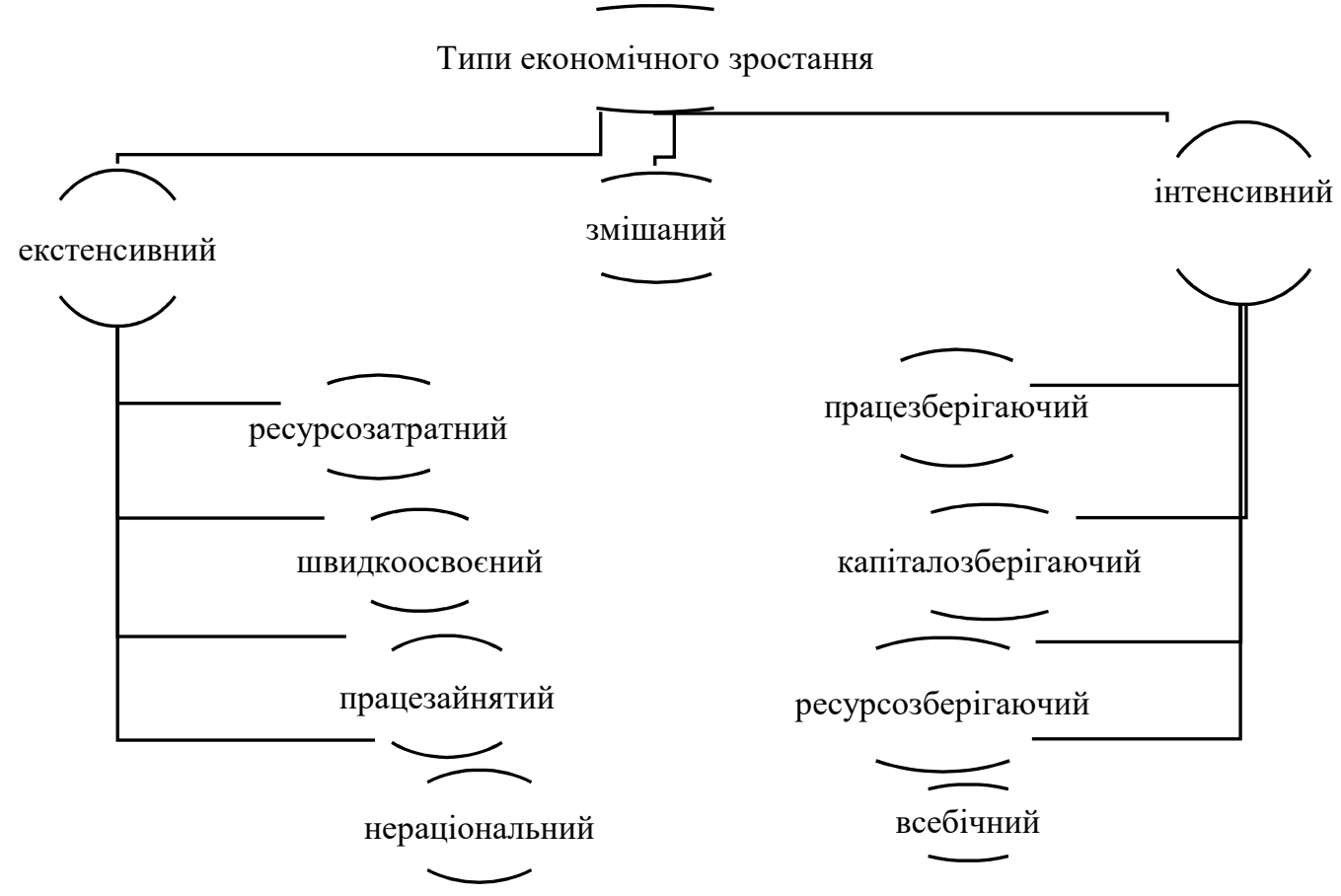

Рис. 3. Типи економічного зростання

Джерело: сформовано авторкою з використанням [15, с. 228].

Екстенсивний тип економічного зростання передбачає нарощування виробництва товарів та послуг за рахунок збільшення чисельності робочої сили, інвестицій та інших ресурсів при незмінній продуктивності праці. Інтенсивний тип економічного зростання передбачає нарощування виробництва товарів та послуг за рахунок підвищення продуктивності праці, покращення організації діяльності та зростання ефективності використання ресурсів. Змішане зростання (всебічна інтенсифікація та екстенсифікація) - це якісне відновлення всього процесу розширеного відтворення.

Також виділяють інші типи економічного зростання:

- рівномірне зростання розвинених країн;

- відсутність економічного зростання;

- «економічне диво»;

- «економічна трагедія» [10, с. 13];

- трансформаційний (фактори виробництва перетворюються у продукт);

- трансакційний (інституційно-організовані зв'язки із соціальною функцією) [19, с. 67].

Узагальнюючи підходи різних концепцій економічного зростання, можна виділити значну кількість чинників із різним вагомим впливом у часовому просторі. Так, одні дослідники акцентують увагу на фундаментальних детермінантах, а інші - оцінюють зовнішні та внутрішні тощо.

Чинники економічного зростання в науковій літературі мають різні трактування:

- детермінанти економічної динаміки [24];

- елементи потенціалу зростання ВВП та інших макроекономічних показників;

- елементи виробництва, які мають забезпечувати зростання ВВП;

- умови приросту ВВП;

- джерела економічного зростання;

- реальні ресурси процесу виробництва;

- процеси та явища, які визначають масштаб економічного зростання [28, с. 28-31]. 
ТЕОРЕТИЧНІ ПРОБЛЕМИ РОЗВИТКУ НАЦІОНАЛЬНОЇ ЕКОНОМІКИ

Д. Родрік у праці «У пошуках процвітання: аналітичні наративи економічного зростання» (2003) наводить один із варіантів узагальнюючої структури чинників впливу на економічне зростання. На його думку, чинники зростання можна поділити на безпосередні та фундаментальні чинники:

- безпосередні чинники (ті, що безпосередньо впливають на економічне зростання): зростання продуктивності праці, накопичення людського та фізичного капіталу;

- фундаментальні чинники (ті, що мають вирішальний вплив на темп економічного зростання та $є$ засадами соціально-економічного розвитку держави): ендогенні (зовнішня торгівля та інститути) та екзогенні (географія) [29, с. 1-19].

Так, науковці Інституту економіки та прогнозування НАН України запропонували структурно-логічну модель оцінювання економічного зростання, де виділили такі детермінанти: природноресурсний капітал, людський капітал, основний капітал, структурна політика, промислова політика, інвестиційна політика та входження у глобальні ланцюжки доданої вартості, інноваційно-технологічна політика, інституційне забезпечення розвитку малого й середнього бізнесу, регіональна політика [10, с. 370-379].

У класичному варіанті економічне зростання формується під впливом попиту та пропозиції. До чинників пропозиції економічного зростання належать природні ресурси, трудові ресурси, капітал та нові технології. Чинники попиту формують економічне зростання через механізм сукупного попиту, використання наявних ресурсів та структури сукупних видатків. Для збільшення сукупного попиту необхідно забезпечувати повну зайнятість для дедалі більшої кількості ресурсів. Власне, чинник попиту проявляється через макроекономічну сферу. Він повинен забезпечувати певний рівень споживання, який має відповідати наявним ресурсам. Для реалізації цього $є$ такі інструменти, як відсоткова ставка, податки та збори, цінова політика.

Чинники попиту і пропозиції перебуває в постійному взаємозв'язку і змінюються під впливом механізмів розподілу ресурсів. Наприклад, повільні темпи інноваційного розвитку та зменшення обсягів інвестування можуть спричинити безробіття. Найкраще такий взаємозв'язок, ілюструє крива виробничих можливостей, яка пояснює можливості одночасного виробництва двох продуктів з урахуванням обмеження ресурсної бази. Тому виділяють третій чинник економічного зростання - чинник розподілу, який характеризує розподіл природних, фінансових та трудових ресурсів країни таким чином, щоб сприяти приросту товарів та послуг, підвищення їхньої якості та вдосконалення виробничих потужностей [8, с. 123].

В. Нордхаус та П. Самуельсон визначають чинниками економічного зростання капітал, природні та людські ресурси [18, с. 125].

Дослідження процесу еволюції чинників економічного зростання та систематизації підходів дозволяє використати певні класифікаційні ознаки їх виокремлення: сфера виникнення, спосіб впливу, походження, тип економічного зростання, напрям впливу, сфери прояву, термін дії, періодичність виникнення, місце створення щодо регіону чи країни, рівень охоплення, рівень регулювання, ступінь мінливості в межах свого типу $[8$, c. 123-125].

В. Ф. Салійчук виділяє три групи дослідження економічного зростання:

1)аналіз методологічних питань теорії економічного зростання, зокрема розгляд поняттєвого апарату;

2)аналіз практики економічного зростання в попередні історично-часові періоди;

3)аналіз практики економічного зростання та розширеного відтворення в різних країнах $[17$, с. 58].

Такий підхід дав можливість сформувати принципово різні напрями дослідження та класифікувати концепції економічного зростання (табл. 2). 
Класифікація напрямів дослідження та концепцій економічного зростання за В. Ф. Салійчуком

\begin{tabular}{|c|c|}
\hline $\begin{array}{l}\text { № } \\
\text { 3/ח }\end{array}$ & Концепції економічного зростання \\
\hline \multicolumn{2}{|r|}{$\begin{array}{l}\text { НАПРЯМ ІДЕНТИФІКАЦІЇ ЕКОНОМІЧНОГО ЗРОСТАННЯ } \\
\text { У ВЗАСМОЗВ ЯЗКУ З ІНШИМИ МАКРОПРОЦЕСАМИ }\end{array}$} \\
\hline 1 & Тотожність економічного зростання та розширеного відтворення \\
\hline 2 & Тотожність економічного зростання та економічного розвитку \\
\hline 3 & Тотожність економічного зростання та економічної динаміки \\
\hline 4 & Тотожність економічного зростання та зростання виробництва \\
\hline 5 & Тотожність економічного зростання та економічного прогресу \\
\hline 6 & Тотожність економічного зростання та зростання ВВП на душу населення \\
\hline 7 & $\begin{array}{l}\text { Тотожність економічного зростання одночасно з розширеним відтворенням та економічною } \\
\text { динамікою }\end{array}$ \\
\hline 8 & Економічне зростання як позитивна динаміка національного господарства \\
\hline \multicolumn{2}{|r|}{ НАПРЯМ ІНДИВІДУАЛІЗАЦІЇ ЕКОНОМІЧНОГО ЗРОСТАННЯ } \\
\hline 9 & Економічне зростання як сукупність процесів трансформації ресурсів виробництва (В. Д. Камаєв) \\
\hline 10 & $\begin{array}{l}\text { Економічне зростання як процес формування приросту фізичного обсягу ВВП у його оптималь- } \\
\text { ній натурально-речовій структурі }\end{array}$ \\
\hline 11 & Економічне зростання як розширене відтворення ВВП (Б. Мінц) \\
\hline
\end{tabular}

Напрям індивідуалізації вважається більш конструктивним з погляду дослідження економічного зростання як явища. Саме прибічники такого процесу пояснюють специфіку економічного зростання як особливого макропроцесу. Так, у 80-х роках XX ст. В. Д. Камаєв запропонував концептуальний підхід дослідження економічного зростання, як явища, що виникає на стадії створення суспільного продукту та виробництва матеріальних благ. У такому випадку економічне зростання можна характеризувати як економічну категорію. Свою увагу В. Д. Камаєв [6] при вивченні економічного зростання звертав увагу на проблему його якості.

Висновки і пропозиції. Формування концепції економічного зростання перебуває у взаємозв'язку з категоріями економічного розвитку та економічної політики. Розгляд еволюції теорій економічного зростання показав адаптацію різних підходів до інноваційних змін в економіці. Огляд трактувань суті поняття «економічного зростання» та спроб уніфікації підходів різних концептуальних засад у науковій літературі, дозволив визначити економічне зростання як пріоритетну мету держави, яка проявлясться у зростанні ВВП та інших альтернативних показників розвитку економічної системи, що забезпечус підвищення якості життя населення в процесі суспільного відтворення. Розмежування економічної динаміки дає можливість виділити економічне зростання як їі різновид з певними специфічними ознаками масштабу сфери виникнення, відтворювального процесу, зростання ВВП та рушія виробництва товарів. Узагальнення підходів різних концепцій економічного зростання дозволив виділити значну кількість чинників з різним вагомим впливом в часовому просторі, яких можна згрупувати у групи чинників попиту, пропозиції та розподілу.

Вважаємо за доцільне при дослідженні поняття «економічне зростання» використовувати принципи єдності ознак; макроекономічного підходу (економіка країни, економіка регіону, економічний союз, світова економіка); обов'язковості виділення об'єктів економічної діяльності; збалансування кількісних та якісних ознак макропроцесів; визначення основних внутрішніх та зовнішніх чинників впливу; визначення системи показників для можливості порівняння різних регіонів чи країн; розмежування економіч- 
ТЕОРЕТИЧНІ ПРОБЛЕМИ РОЗВИТКУ НАЦІОНАЛЬНОЇ ЕКОНОМІКИ

ної динаміки зростання, розвитку, прогресу, росту виробництва та суспільного відтворення; врахування умов (економічних, соціальних, культурних, історичних); активізації інвестиційного потенціалу; «rent-seeking behavior»; цілісності, системності, ієрархічності та структурності.

\section{Список використаних джерел}

1. Буторіна В.Б. Науково-технічний прогрес у моделях економічного зростання. Вісник Кам'янець-Подільського університету імені Івана Огієнка. Економічні науки. 2014. № 9. С. 17-20.

2. Васюренко О. В. Банківські операції : навчальний посібник. Київ : Знання, 2006. 255 с.

3. Глуха Г. Я. Економічне зростання: еволюційно-змістовий аналіз. Академічний огляд. 2013. № 1(38). C. 32-38. http://acadrev.duan.edu.ua/images/PDF/2013/1/5.pdf.

4. Економіка розвитку: дослідження технологій переходу країн до прискореного стійкого економічного зростання. Сайт експертно-аналітичного центру «Оптіма». http://optimacenter.org/research/ekonomika-rozvytku-doslidzhennja-tehnologij-perehodu-krajin-dopryskorenogo-stijkogo-ekonomichnogo-zrostannja.

5. Загорський В. С. Концептуальні основи формування системи управління сталим розвитком еколого-економічних систем: монографія. Львів : ЛРІДУ НАДУ, 2018. 336 с.

6. Камаев В. Д., Ильчиков М. З., Борисовская Т. А. Экономическая теория : учебник. 4-е издание, стереотипное. Москва : Кнорус, 2010. 384 с.

7. Лутчин Н. П. Статистичне вивчення якості та стійкості економічного зростання: регіональний аспект. Вісник Київського національного університету імені Тараса Шевченка. 2011. № 129. С. 29-32.

8. Магдіч А. С. Типологія факторів економічного зростання: теоретико-методологічний аспект. Свропейський вектор економічного розвитку. 2015. № 2(19). С. 119-130.

9. Мочерний С. В. Політекономія. 2-ге вид. Київ : Вікар, 2005. 386 с.

10. Національні та глобальні детермінанти економічного зростання України: наукова доповідь / за ред. д.е.н. І. М. Бобух. Київ, 2018. 390 с.

11. Небава М. І. Теорія макроекономіки : навч. посіб. для студ. екон. спец. Вінниця : УНІВЕРСУМ-Вінниця, 2001. 395 с.

12. Оголь Д.О. Економічне зростання: сутність, якість і стійкість. Актуальні проблеми економіки. 2015. № 2(164). С. 67-72.

13. Пилип’юк Я. В. Концептуалізація сутності інноваційного розвитку держави. Бізнес Iнформ. 2014. № 9. С. 109-114.

14. Піхняк Т. А., Вінідіктова І. С., Кабаці Б. І. Сутність та види економічного зростання. Науковий вісник НЛТУ Украӥни. 2010. Вип. 20.10. С. 130-136.

15. Покровська Н. М. Економічна сутність поняття «інтенсифікація виробництва» Економічний вісник НТУУ «КПІ»: збірник наук. праць. 2015. № 12. С. 224-229.

16. Приходько В. П. Принципи активізації інвестиційного потенціалу в регіональній політиці економічного зростання. Ефективна економіка. 2011. № 6. http://www.economy.nayka.com.ua/ $? \mathrm{op}=1 \& \mathrm{z}=1115$.

17. Салийчук В. Ф. Экономический рост: эволюция современных концепций. Вестник Удмуртского университета. Экономика и право. 2008. № 1. С. 57-70.

18. Самуэльсон П. Экономика : [в 2 т.]. Москва : Алгон ; ВНИИСИ, 1992. Т. 1. 335 с.

19. Семків Л. Є. Економічне зростання як індикатор якості економічних реформ. Науковий вісник Мукачівського державного університету. Серія Економіка. 2015. № 2(4), ч. 2. С. 66-70.

20. Ходжаян А. Р. Поняття структури і структурних трансформацій у системі економічних процесів. Проблеми і перспективи економіки та управління. 2017. № 4(12). С. 42-54.

21. Хоменко Я. В. Генезис теорії економічного зростання. Інженерна освіта у розвитку сучасного суспільства : матеріали Міжнародної наук.-практ. конференції (м. Донецьк, 2011 р.). Донецьк : ДВНЗ «Донец. нац. техн. ун-т», 2011. С. 483-494.

22. Цанько О. О. Принципи сталого розвитку і проблеми формування державної інвестиційної політики. Ефективність державного управління. 2017. № 4(53), ч. 2. С. 189-196.

23. Шумпетер Й. Теория экономического развития. Москва : Прогресс, 1982. $401 \mathrm{c}$. 
24. Arvanitidis P., Pavleas S., Petrakos G., Determinants of economic growth: the view of the experts. University of Thessaly, Department of Planning and Regional Development. 2009. № 15(1). https://www.researchgate.net/publication/23528914_Determinants_of_economic_growth_the_experts' view.

25. Benhabib J., Mark M. The role of human capital in economic development evidence from aggregate cross-country data. Journal of Monetary Economics. Spiegel. 1994. Vol. 34(2). P. 143-173.

26. Kuznets S. Economic Growth and Income Inequality. American Economic Review. 1955. Vol. 65. P. 1-28.

27. Kuznets S. Measurement: Measurement of Economic Growth. The Journal of Economic History. 1947. Vol. 7. P. 10-34.

28. Mishulin G. M., Stjagun A. V. Determination of the concept of economic growth in the paradigm of the institutional approach. Terra Economicus. Economic Herald of Rostov State University, 2008. Vol. 6. № 2-3. P. 27-32.

29. Rodrik D. In search of prosperity: Analytic narratives on economic growth. Princeton University Press, 2003. 481 p.

30. Rostow W. W. The Process of Economic Growth. New York: W. W. Norton \& Company Inc., $1962.372 \mathrm{p}$.

31. Sen A. Development: Which Way Now? Economic Journal. 1983. Vol. 93, No. 372. P. 745-762.

32. Schumpeter J. Business Cycles. New York, 1939. Vol. 1.

33. Solow Robert M. Contribution to the Theory of Economic Growth. The Quarterly Journal of Economics, 1956. Vol. 70. Pp. 65-94. http://piketty.pse.ens.fr/files/Solow1956.pdf.

\section{References}

1. Butorina, V. B. (2014). Naukovo-tekhnichnyj prohres u modeliakh ekonomichnoho zrostannia [Scientific and technological progress in models of economic growth]. Visnyk Kamianets-Podilskoho universytetu imeni Ivana Ohiienka. Ekonomichni nauky - Bulletin of Ivan Ogienko University of Kamyanets-Podilsky. Economic sciences, 9, pp. 17-20.

2. Vasiurenko, O. V. (2006). Bankivski operatsii [Banking operations]. Znannia.

3. Hlukha, H. Ya. (2013). Ekonomichne zrostannia: evoliutsijno-zmistovyj analiz [Economic growth: evolutionary content analysis]. Akademichnyi ohliad - Academic review, 1(38), pp. 32-38. http://acadrev.duan.edu.ua/images/PDF/2013/1/5.pdf.

4. Sait ekspertno-analitychnoho tsentru "Optima" [The site of the expert-analytical center "Optima"]. Ekonomika rozvytku: doslidzhennia tekhnolohii perekhodu krain do pryskorenoho stijkoho ekonomichnoho zrostannia - Development Economics: a study of technologies for the transition of countries to accelerated sustainable economic growth. http://optimacenter.org/ research/ekonomika-rozvytku-doslidzhennja-tehnologij-perehodu-krajin-do-pryskorenogo-stijkogoekonomichnogo-zrostannja-.

5. Zahorskyi, S. (2018). Kontseptualni osnovy formuvannia systemy upravlinnia stalym rozvytkom ekoloho-ekonomichnykh system [Conceptual bases of formation of management system of sustainable development of ecological and economic systems]. LRIDU NADU.

6. Kamaev, V. D., Ilchykov, M. Z., \&Borysovskaia, T. A. (2010). Ekonomicheskaia teoriia [Economic theory] (4nd ed.). Knorus.

7. Lutchyn, N. P. (2011). Statystychne vyvchennia iakosti ta stijkosti ekonomichnoho zrostannia: rehional'nyj aspekt [Statistical study of quality and stability of economic growth: regional aspect]. Visnyk Kyivskoho natsionalnoho universytetu imeni Tarasa Shevchenka - Bulletin of the Taras Shevchenko National University of Kyiv, 129, pp. 29-32.

8. Mahdich, A. S. (2015). Typolohiia faktoriv ekonomichnoho zrostannia: teoretykometodolohichnyj aspect [Typology of factors of economic growth: theoretical and methodological aspect]. Yevropeiskyi vektor ekonomichnoho rozvytku - European vector of economic development, 2(19), pp. 119-130.

9. Mochernyi, S. V. (2005). Politekonomiia [Political Economy]. (2nd ed.). Vikar.

10. Bobukh, I. M. (2018). Natsionalni ta hlobalni determinanty ekonomichnoho zrostannia Ukrainy [National and global determinants of Ukraine's economic growth]. Natsionalna akademiia nauk Ukrainy Institut ekonimiky ta prohnozuvannia. 
ТЕОРЕТИЧНІ ПРОБЛЕМИ РОЗВИТКУ НАЦІОНАЛЬНОЇ ЕКОНОМІКИ

11. Nebava, M. I. (2001). Teoriia makroekonomiky [Theory of macroeconomics]. UNIVERSUMVinnytsia.

12. Ohol, D. O. (2015). Ekonomichne zrostannia: sutnist, iakist i stiikist [Economic growth: essence, quality and sustainability]. Aktualni problemy ekonomiky - Actual problems of economy, 2(164), pp. 67-72.

13. Pylypiuk, Ya. V. (2014). Kontseptualizatsiia sutnosti innovatsijnoho rozvytku derzhavy [Conceptualization of the essence of innovative development of the state]. Biznes Inform - Business Inform, 9, pp. 109-114.

14. Pikhniak, T. A., \& Vinidiktova, I. S., \&Kabatsi, B. I. (2010). Sutnist ta vydy ekonomichnoho zrostannia [The essence and types of economic growth]. Naukovyj visnyk NLTU Ukrainy - Scientific Bulletin of NLTU of Ukraine, 20.10, pp. 130-136.

15. Pokrovska, N. M. (2015). Ekonomichna sutnist poniattia "intensyfikatsiia vyrobnytstva" [The economic essence of the concept of "intensification of production"]. Ekonomichnyi visnyk "KPI" Economic Bulletin of "KPI”, 12, pp. 224-229.

16. Prykhodko, V. P. (2011). Pryntsypy aktyvizatsii investytsiinoho potentsialu v rehionalnii politytsi ekonomichnoho zrostannia [Principles of activation of investment potential in the regional policy of economic growth]. Efektyvna ekonomika - Effective economy, 6. http://www.economy.nayka.com.ua/?op=1\&z=1115.

17. Salyichuk, V. F. (2008). Ekonomycheskyi rost: evoliutsiia sovremennykh kontseptsyi [Economic growth: the evolution of modern concepts]. Vestnik Udmurtskogo unyversiteta. Ekonomika i pravo - Bulletin of Udmurt University. Economics and law, 1, pp. 57-70.

18. Samuelson, P. (1992). Ekonomyka [Economics]. (Vol. 1). Algon.

19. Semkiv, L. Ye. (2015). Ekonomichne zrostannia iak indykator iakosti ekonomichnykh reform [Economic growth as an indicator of the quality of economic reforms]. Naukovyi visnyk Mukachivskoho derzhavnoho universytetu. Seriia Ekonomika - Scientific Bulletin of Mukachevo State University. Economics series, 2(2(4)), pp. 66-70.

20. Khodzhaian, A. R. (2017). Poniattia struktury i strukturnykh transformatsii u systemi ekonomichnykh protsesiv [The concept of structure and structural transformations in the system of economic processes]. Problemy i perspektyvy ekonomiky ta upravlinnia - Problems and prospects of economy and management, 4(12), pp. 42-54.

21. Khomenko, Ya. V. (2011). Henezys teorii ekonomichnoho zrostannia [Genesis of the theory of economic growth]. Inzhenerna osvita u rozvytku suchasnoho suspilstva - Engineering education in the development of modern society: Proceedings of the International Scientific and Practical Conference, (pp. 483-494). DVNZ «Donetskyi natsionalnyi tekhnichnyi unyversytet».

22. Tsanko, O. O. (2017). Pryntsypy staloho rozvytku i problemy formuvannia derzhavnoi investytsijnoi polityky [Principles of sustainable development and problems of formation of the state investment policy]. Efektyvnist derzhavnoho upravlinnia - Efficiency of public administration, 4(53)(2), pp. 189-196.

23. Shumpeter, J. (1982). Teoriia ekonomicheskoho razvitiia [Theory of Economic Development]. Prohress.

24. Arvanitidis, P., Pavleas, S., \& Petrakos, G. (2009). Determinants of economic growth: the view of the experts. University of Thessaly, Department of Planning and Regional Development, 15(1). https://www.researchgate.net/publication/23528914_Determinants_of_economic_growth_the_experts' view.

25. Benhabib, Jess, \& Mark, M. (1994). The role of human capital in economic development evidence from aggregate cross-country data. Journal of Monetary Economics. Spiegel, 34(2), pp. 143-173.

26. Kuznets, S. (1955). Economic Growth and Income Inequality. American Economic Review, 65 , pp. 1-28.

27. Kuznets, S. (1947). Measurement: Measurement of Economic Growth. The Journal of Economic History, 7, pp. 10-34.

28. Mishulin, G. M., \& Stjagun, A. V. (2008). Determination of the concept of economic growth in the paradigm of the institutional approach. Terra Economicus. Economic Herald of Rostov State University, 6(2-3), pp. 27-32. 
29. Rodrik, D. (2003) In search of prosperity: Analytic narratives on economic growth. Princeton University Press.

30. Rostow, W. W. (1962). The Process of Economic Growth. W. W. Norton \& Company Inc.

31. Sen, A. (1983). Development: Which Way Now? Economic Journal, 93(372), pp. 745-762.

32. Schumpeter, J. (1939). Business Cycles. (Vol. 1). New York.

33. Solow, Robert M. (1956). Contribution to the Theory of Economic Growth. The Quarterly Journal of Economics, 70, pp. 65-94. http://piketty.pse.ens.fr/files/Solow1956.pdf.

Рудевська Вікторія Ігорівна - кандидат економічних наук, доцент, доцент кафедри банківської справи та фі-

нансових технологій, Навчально-науковий інститут банківських технологій та бізнесу Університету банківської справи (вул. Андріївська, 1, м. Київ, 04070, Україна).

Рудевская Виктория Игоревна - кандидат экономических наук, доцент, доцент кафедры банковского дела и финансовых технологий, Учебно-научный институт банковских технологий и бизнеса Университета банковского дела (ул. Андреевская, 1, г. Киев, 04070, Украина).

Rudevska Viktoria - PhD in Economics, Associate Professor, Associate Professor of Department of Banking and Finance Technologies, Educational and Scientific Institute of Banking Technologies and Business of Banking University (1 Andriivska Str., 04070 Kyiv, Ukraine).

E-mail: rudevska@ukr.net

ORCID: https://orcid.org/0000-0001-6697-9096

ResearcherID: K-8854-2015

Scopus Author ID: 57193157107

Рудевська В. Еволюція теорій економічного зростання та чинники його оцінювання. Проблеми і перспективи економіки та управління. 2020. № 2 (22). С. 18-30. 